TABLE 1. Continued

\begin{tabular}{lccccccccc}
\hline Case & $\begin{array}{c}\text { First author } \\
\text { and year }\end{array}$ & $\begin{array}{c}\text { Age } \\
(\mathbf{y})\end{array}$ & $\begin{array}{c}\text { Sex } \\
\text { presentation }\end{array}$ & $\begin{array}{c}\text { Clinical } \\
\text { access }\end{array}$ & Tumor site & CPB & $\begin{array}{c}\text { Surgical } \\
\text { procedure }\end{array}$ & Outcome & Pathology \\
\hline 29 & Sogawa 2012 & 73 & M & NA & Sternotomy & RVOT & Y & Total excision & Alive and well, Cardiac hemangioma \\
30 & Jiang 2013 & 49 & M & NA & Sternotomy & Apex of RV & Y & Total excision & $\begin{array}{c}\text { Alive and well, Cardiac hemangioma } \\
6 \text { mo }\end{array}$
\end{tabular}

$C P B$, Cardiopulmonary bypass; $F$, female; $R V$, right ventricle; $N A$, not available; $R A$, right atrium; $M$, male; $R V O T$, right ventricular outflow tract; $R H$, right heart; $L V$, left ventricle; $P A$, pulmonary artery; $A o$, aorta.

\title{
Functioning Cooley-Cutter aortic valve prosthesis 40 years after implantation
}

\author{
Sahar A. Saddoughi, ${ }^{a}$ Daniel H. Steinberg, MD, ${ }^{\mathrm{b}}$ and John S. Ikonomidis, MD, PhD, ${ }^{\mathrm{a}}$ Charleston, SC
}

Video clip is available online.

The development of artificial heart valves has revolutionized cardiac surgery. During the past 60 years, heart valve prostheses have evolved considerably, with each new model designed with the hope of better hemodynamics and outcomes for patients. The Cooley-Cutter heart valve was designed in the 1960s by Denton A. Cooley, MD, in collaboration with Cutter Laboratories and introduced for clinical use in 1971. ${ }^{1}$ The device used 2 sets of titanium struts to contain a biconic occluder composed of pyrolytic carbon. Cooley-Cutter heart valves were used frequently in the $1970 \mathrm{~s},{ }^{2}$ with Dr Cooley alone having implanted the device in a total of 3275 patients (1786 in the aortic position and 1475 in the mitral) over a 10-year period, with very good clinical results. ${ }^{3}$ Since that time, newer mechanical valves have replaced the Cooley-Cutter valve.

\section{CLINICAL SUMMARY}

An 85-year-old man with a medical history significant for diabetes, coronary artery disease, previous stent placement

\footnotetext{
From the Division of Cardiothoracic Surgery, ${ }^{\mathrm{a}}$ and the Department of Cardiology, ${ }^{\mathrm{b}}$ Medical University of South Carolina, Charleston, SC.

Disclosures: Authors have nothing to disclose with regard to commercial support.

Received for publication Oct 18, 2013; accepted for publication Oct 28, 2013; available ahead of print Dec 2, 2013.

Address for reprints: John S. Ikonomidis, MD, PhD, Division of Cardiothoracic Surgery, Medical University of South Carolina, Suite 7030, 25 Courtney Dr,

Charleston, SC 29425-2950 (E-mail: ikonomij@musc.edu).

J Thorac Cardiovasc Surg 2014;147:e21-2

$0022-5223 / \$ 36.00$

Copyright (C) 2014 by The American Association for Thoracic Surgery

http://dx.doi.org/10.1016/j.jtcvs.2013.10.068
}

in the left anterior descending coronary artery, and previous mechanical aortic valve replacement was seen for dyspnea on exertion and minor weight loss. The patient's surgical history was significant for aortic valve replacement with a Cooley-Cutter prosthesis, implanted by Dr Cooley at the Texas Heart Institute on October 4, 1973. Results of physical examination were unremarkable; cardiac examination revealed regular rate and rhythm with $\mathrm{S} 1$ and $\mathrm{S} 2$, no S3 or S4, and no appreciable murmurs, rubs, or gallops.

Transthoracic echocardiography (Figure 1) showed an intact aortic valve replacement. The valve was properly seated with normal occluder motion. The peak transvalvular velocity was $3.4 \mathrm{~m} / \mathrm{s}$, with a mean gradient of $24 \mathrm{~mm} \mathrm{Hg}$. The left ventricular ejection fraction was calculated to be $60 \%$.

\section{DISCUSSION}

A recent single-center retrospective review of the results of the use of the St Jude mechanical valve $e^{4}$ demonstrated a 25 -year survival of $17 \% \pm 4 \%$. In the context of these results, it is high unusual to document such excellent functional results as those of this 40-year-old Cooley-Cutter prosthesis. Another mechanical aortic valve prosthesis that has been shown to be remarkably durable in certain cases is the Starr-Edwards prosthesis. ${ }^{5}$ Our patient's symptoms were ultimately found to be unrelated to his cardiac history, and he currently remains well controlled on warfarin. Overall, the prosthetic valve remains in excellent condition with no need for replacement.

\footnotetext{
References

1. Roe BB. "Extinct" cardiac valve prostheses. In: Bodnar E, Frater R, eds Replacement cardiac valves. New York: Pergamon Press; 1991:307-32.
} 


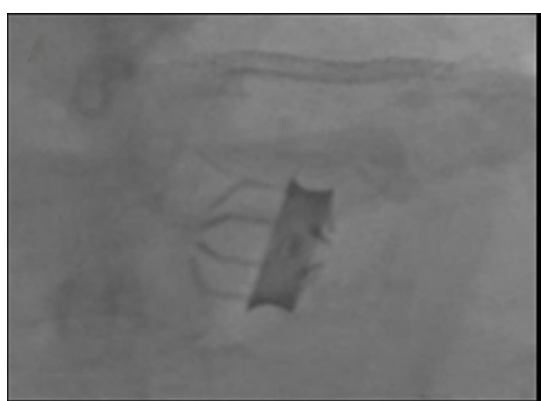

A

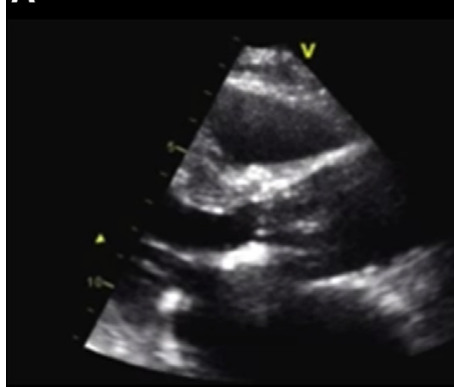

C

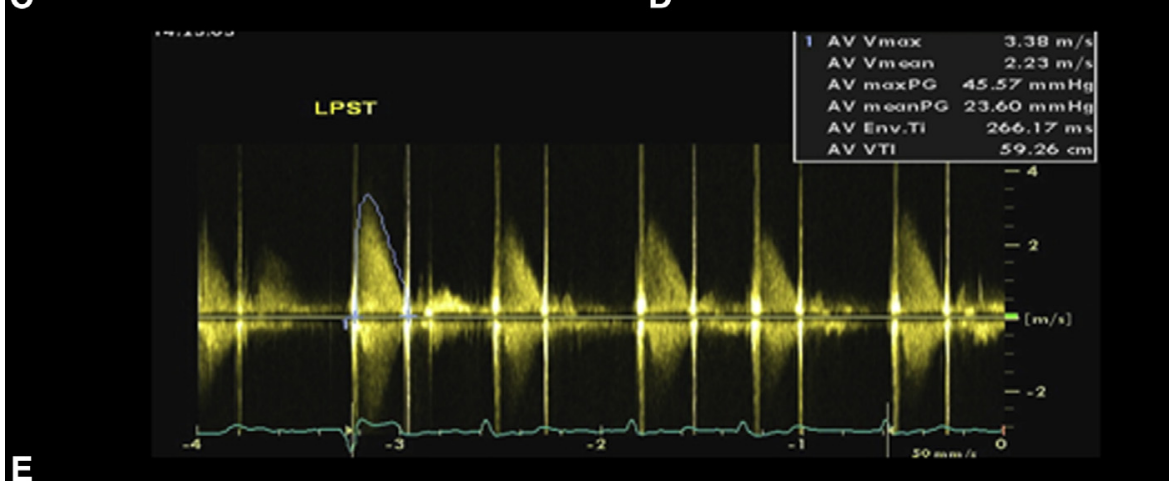

FIGURE 1. Cooley-Cutter aortic valve in situ. Fluoroscopic images of the valve in diastole (A) and in systole (B). Parasternal long-axis view depicting the valve in diastole (C) and in systole (D). E, Continuous-wave Doppler from the left parasternal position demonstrating a peak transvalvular velocity of $3.4 \mathrm{~m} / \mathrm{s}$ with a mean gradient of $24 \mathrm{~mm} \mathrm{Hg}$.

2. Gott VL, Alejo DE, Cameron DE. Mechanical heart valves: 50 years of evolution. Ann Thorac Surg. 2003; 76:S2230-9.

3. Cooley DA, Okies JE, Wukasch DC, Sandiford FM, Hallman GL. Ten year experience with cardiac replacement: results with a new prosthesis. Ann Surg. $1973 ; 177: 818-26$
4. Toole JM, Stroud MR, Kratz JM, Crumbley AJ 3rd, Bradley SM, Crawford FA Jr, et al. Twenty-five year experience with the St. Jude medical mechanical valve prosthesis. Ann Thorac Surg. 2010;89:1402-9.

5. Saxena P, Bonnichsen CR, Greason KL. Starr-Edwards aortic valve: forty-four years old and still working! J Thorac Cardiovasc Surg. 2013;146:e21-2. 